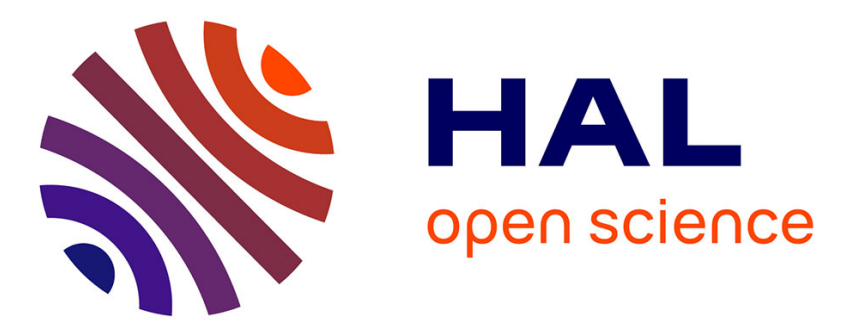

\title{
Inventory of echinoderms in the Iles Eparses (Europa, Glorieuses, Juan de Nova), Mozambique Channel, France
}

Chantal Conand, Thierry Mulochau, Sabine Stöhr, Marc Eléaume, Pascale Chabanet

\section{To cite this version:}

Chantal Conand, Thierry Mulochau, Sabine Stöhr, Marc Eléaume, Pascale Chabanet. Inventory of echinoderms in the Iles Eparses (Europa, Glorieuses, Juan de Nova), Mozambique Channel, France. Acta Oecologica, 2016, 72, pp.53-61. 10.1016/j.actao.2015.06.007 . hal-01306705

\section{HAL Id: hal-01306705 https: / hal.univ-reunion.fr/hal-01306705}

Submitted on 26 Apr 2016

HAL is a multi-disciplinary open access archive for the deposit and dissemination of scientific research documents, whether they are published or not. The documents may come from teaching and research institutions in France or abroad, or from public or private research centers.
L'archive ouverte pluridisciplinaire HAL, est destinée au dépôt et à la diffusion de documents scientifiques de niveau recherche, publiés ou non, émanant des établissements d'enseignement et de recherche français ou étrangers, des laboratoires publics ou privés. 


\title{
Inventory of echinoderms in the Iles Eparses (Europa, Glorieuses, Juan de Nova), Mozambique Channel, France
}

\author{
C. Conand ${ }^{\text {a, b, }{ }^{*}, \text { T. Mulochau }}{ }^{\text {c }}$ S. Stöhr ${ }^{\text {d }}$, M. Eléaume ${ }^{\text {b }}$, P. Chabanet ${ }^{\mathrm{e}}$ \\ a Ecomar, Université de La Réunion, 97715 La Réunion, France \\ b Département Milieux et Peuplements Aquatiques, MNHN, 47 rue Cuvier, 75005 Paris, France \\ ${ }^{c}$ BIORECIF, 3 ter rue de l'albatros, 97434 La Réunion, France \\ d Swedish Museum of Natural History, Frescativägen 40, 11418 Stockholm, Sweden \\ e IRD, BP 50172, 97492 Ste Clotilde, La Réunion, France
}

\begin{abstract}
A B S T R A C T
The multidisciplinary programme BioReCIE (Biodiversity, Resources and Conservation of coral reefs at Eparses Is.) inventoried multiple marine animal groups in order to provide information on the coral reef health of the Iles Eparses. All five classes of echinoderms were observed by visual census, photographed and later identified. About 100 species are reported, including a few unidentified ones which require further studies. The Holothuroidea and Ophiuroidea are the most diverse. One new species, the asterinid Aquilonastra chantalae O'Loughlin and McKenzie (2013), was discovered in addition to several new records of echinoderms. The illegal fishery targeting holothurians, which are presently highly valuable resources in this zone, is discussed.
\end{abstract}

\section{Introduction}

The Iles Eparses (Scattered Islands) are isolated uninhabited French islands, in the South West Indian Ocean. These islands provide ideal conditions for evaluating marine biodiversity that has not been affected by anthropogenic influences. The multidisciplinary programme BioReCIE (Biodiversity, Resources and Conservation of coral reefs at Eparses Is.) undertook an inventory of several marine groups in order to provide information on the health of coral reefs on these islands (Chabanet et al., 2013, 2014a, 2014b, submitted for publication).

Few studies have been conducted on echinoderms from Iles Eparses (Vergonzannes, 1977; Quod et al., 2007; Mulochau and

Abbreviations: ASFMA, Australian Fisheries Management Authority; IUU, illegal, unreported and unregulated fishing; MNHN, Muséum national d'Histoire naturelle, Paris; O, occurrence; rf, reef flat; rs, reef slope; sp., species; TAAF, Terres Australes et Antarctiques Françaises; WIO, Western Indian Ocean.

* Corresponding author. Ecomar, Université de La Réunion, 97715 La Réunion, France.

E-mail address: conand@univ-reunion.fr (C. Conand).
Conand, 2008). The BioReCIE programme has recently provided data on Europa echinoderms (Conand et al., 2013) and on Glorieuses holothurians (Conand et al., 2014). Other studies on echinoderms have been conducted in several countries of the SW Indian Ocean region, on one class, or the whole phylum (Conand and Muthiga, 2007 and Muthiga and Conand, 2014); as for example on the holothurians of Kenya, Madagascar, Reunion, Seychelles and Tanzania; Conand, 2008; Conand et al., 2010; Eriksson et al., 2015; Samyn et al., 2006; Samyn and Tallon, 2005; FAO, 2013; Hoareau et al., 2013; O'Loughlin and McKenzie, 2013; Rowe and Richmond, 2011).

Although the Iles Eparses are generally described as pristine environments, some illegal fisheries for holothurians have developed in recent years (Conand et al., 2014). Illegal, Unreported and Unregulated Fishing (IUU) has recently caught international attention (FAO, 2001; Le Gallic, 2007). As the socioeconomic importance of holothurians has now been recognized (Purcell et al., 2013), threats to the resources will be discussed.

The objective of this paper is to report new data and synthesize our knowledge on the echinoderms in the Iles Eparses. 


\section{Material and methods}

The study areas of each archipelago and the general survey methods have already been presented in other contributions of this issue (Chabanet et al. 2014b submitted for publication; Poupin,in this issue) or in the other papers already published on echinoderms from the programme BioReCIE (Conand et al., 2013, 2014) and will not be detailed here. The list of the stations visited in Europa, Glorieuses and Juan de Nova is given in Appendix A (Tables A.1, A.2 and A.3), with the date, GPS position, depth and habitat, as presented by Poupin (in this issue) for the Crustacea of the programme.

Representatives of all five echinoderm classes were observed by visual census at low tide on reef flats or by SCUBA diving down to $20 \mathrm{~m}$, on the reef slopes. Some individuals were sampled and photographed for identification. Several taxonomists have assisted with specimen identification (see Acknowledgements). The taxonomy follows the World Register of Marine Species (Boxshall et al., 2014).

Despite various geomorphologic descriptors used on the field (see Appendices), the habitats have been brought together as two main categories: reef flat (RF) and outer reef slope (OR) to allow a first general comparison in these islands. To show the relative presence of each echinoderm species at each island, its occurrence has been calculated, defined as the number of stations ( $\mathrm{n}$ ) where it was present in a specific habitat (RF or OR), divided by the total number of stations $(\mathrm{N})$ studied for this habitat.

When available, the populations of some species have also been categorized from the field observations, as dense or sparse.

Information on illegal fisheries for sea cucumbers in the Iles Eparses have been obtained from TAAF and ASFMA (see Abbreviations).

\section{Results}

A synthetic view of the general diversity of echinoderms in the Iles Eparses is presented in Table 1.

The taxonomic diversity differs between classes. Based on our sampling programme, the Holothuroidea and Ophiuroidea were the most diverse, with 31 species each (including 4 and 6 unidentified species respectively). The Crinoidea were the least diverse, with only 9 species (including 3 species not identified). The Asteroidea with 11 species ( 1 not identified) and the Echinoidea with 16 species ( 2 not identified) showed an intermediate diversity, from the results of this programme. In total, about 100 species were found (including 12 unidentified species, whose specimens were often juveniles). One new species, the asteroid Aquilonastra chantalae O'Loughlin and McKenzie (2013), has been discovered (O'Loughlin and McKenzie, 2013) and has been deposited and registered as MNHN IE-2013-617 at the Muséum national d'Histoire naturelle, Paris (MNHN).

All echinoderms from Europa collected during the BioReCIE

Table 1

Diversity in number of species of Echinoderms, by class and total, in the Eparses Islands (Europa, Juan de Nova and Glorieuses), from the BioReCIE programme.

\begin{tabular}{lcccc}
\hline Classes & Europa & Juan de Nova & Glorieuses & Total \\
\hline Asteroidea & 5 & 7 & 8 & 13 \\
Ophiuroidea & 13 & 16 & 17 & 31 \\
Echinoidea & 8 & 10 & 11 & 16 \\
Holothuroidea & 8 & 21 & 20 & 31 \\
Crinoidea & 4 & 6 & 3 & 9 \\
Total & $\mathbf{3 8}$ & $\mathbf{6 0}$ & $\mathbf{5 9}$ & $\mathbf{1 0 0}$ \\
\hline
\end{tabular}

expedition will be catalogued and housed at the Museum national d'Histoire naturelle, Paris; most of the brittle stars collected from Glorieuses and Juan are housed at the Swedish Museum of Natural History, Stockholm.

The echinoderm species are presented by class and by family, in the Tables 2-6 (including new records), with the occurrence of each species calculated for the main habitats ( $R F$ and OR) for each island, and then in total for the results from this programme, allowing comparisons with other sites in the WIO.

The Holothuroidea sampled were represented by five families (Table 2). The family Holothuriidae was the most diverse with 19 species identified +3 unidentified including 1 juvenile Holothuria. The diversity on the reef flats, with 17 species, is nearly twice as high as on the slopes, with 9 species. The species with total occurrence over, or near 0.20 will be presented here. Ranked by decreasing occurrences, Bohadschia atra shows the highest value (0.38), followed by Holothuria nobilis (0.25), Holothuria atra (0.23) and Bohadschia subrubra (0.21).

Four species belong to the family Stichopodidae. Stichopus chloronotus, with dense populations on reef flats, had an occurrence of 0.23 and Thelenota ananas, mostly found on slopes, has 0.180 .

The other families have a low diversity, with 1 Sclerodactilidae Afrocucumis africana, 2 Synaptidae +1 Patinapta sp. and 1 Chiridotidae.

Fourteen species are considered as new records, from the results of BioReCIE (including the species presented in Conand et al., 2013 for Europa and Conand et al., 2014 for Glorieuses); several species had been reported in Cherbonnier's study of Madagascar (1988); 11 species are from the family Holothuriidae.

The Ophiuroidea were represented by 8 families, all from the order Ophiurida (Table 3). As the systematics of this class is rapidly changing (O'Hara et al., 2014), the families are presented in the following order. The Ophiuridae was represented by 1 species, Ophiura kinbergi, found at 2 sites. The Ophiodermatidae were represented by 2 species, Ophiarachnella gorgonia and Ophiopeza fallax. The Ophiocomidae was the most diverse family and was represented by 13 species, including Ophiocoma erinaceus which showed the highest occurrence (0.24), followed by Ophiocoma (Breviturma) brevipes and Ophiocoma cynthiae (0.23). The Ophiotrichidae were represented by 4 identified species and 1 Ophiothela sp. The species in the other families had a low diversity and occurrence: the Ophiolepididae with 1 species and 1 juvenile of the same genus Ophiolepis, the Ophiactidae with 2 species of Ophiactis, with Ophiactis savignyi at Europa and Juan de Nova and 1 unidentified of the same genus, the Ophionereididae with 3 species of the genus Ophionereis only found at Juan, and finally the Amphiuridae, with the only species Amphipholis squamata found at Europa. A cryptic black species, common in coral patches, was not collected (Conand et al., 2013).

Assessing the number of new records of ophiuroids is difficult, since several of the morphologically identified species have been found to comprise several genetic lineages that may have to be treated as separate species (Hoareau et al., 2013), which may revert to currently synonymized names. Since the morphological differences of these genetic lineages have not been worked out, we treat the species found by this study as operational units under the currently valid species names, bearing in mind that some may actually be species complexes. This allows comparison with previous studies. Twelve species are regarded as new for the Eparses Islands (including those reported by Conand et al., 2013 for Europa), but most of them have previously been recorded from the Mozambique Channel at Inhaca (Clark, 1980) and/or at Madagascar (Cherbonnier and Guille, 1978). Ophiocoma doederleini appears to be a new record for the area, possibly also Ophiocoma dentata if its identity is confirmed (although it may previously have been 
Table 2

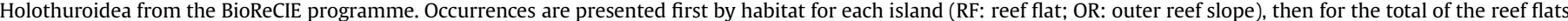

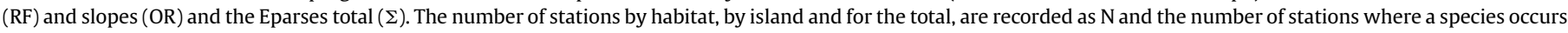
as n. New records for Iles Eparses are marked by*.

\begin{tabular}{|c|c|c|c|c|c|c|c|c|c|c|c|c|c|c|c|}
\hline & \multicolumn{4}{|l|}{ Europa } & \multicolumn{4}{|c|}{ Juan de Nova } & \multicolumn{4}{|l|}{ Glorieuses } & \multicolumn{3}{|c|}{ Eparses (total) } \\
\hline & $\mathrm{RF} N=14$ & $\mathrm{n}$ & OR $N=10$ & $\mathrm{n}$ & $\mathrm{RF} N=21$ & $\mathrm{n}$ & $\mathrm{OR} \mathrm{N}=4$ & $\mathrm{n}$ & $\mathrm{RF} N=12$ & $\mathrm{n}$ & OR $N=10$ & $\mathrm{n}$ & $\mathrm{RF} N=47$ & OR N $=24$ & $\Sigma N=71$ \\
\hline \multicolumn{16}{|l|}{ Family Holothuriidae } \\
\hline Actinopyga echinites* & & & & & 0.05 & 1 & & & & & & & 0.021 & & 0.014 \\
\hline Actinopyga mauritiana & & & & & 0.19 & 4 & & & 0.25 & 3 & & & 0.149 & & 0.099 \\
\hline Actinopyga miliaris* & & & & & 0.14 & 3 & & & & & & & 0.064 & & 0.042 \\
\hline Actinopyga obesa* & & & & & 0.10 & 2 & 0.75 & 3 & & & & & 0.043 & 0.125 & 0.070 \\
\hline Bohadschia atra & 0.21 & 3 & 0.1 & 1 & 0.38 & 8 & 0.25 & 1 & 0.42 & 5 & 0.90 & 9 & 0.340 & 0.458 & 0.380 \\
\hline Bohadschia koellikeri* & & & & & & & & & 0.08 & 1 & & & 0.021 & & 0.014 \\
\hline Bohadschia subrubra & 0.07 & 1 & & & 0.43 & 9 & 0.25 & 1 & 0.33 & 4 & & & 0.298 & 0.042 & 0.211 \\
\hline Bohadschia vitiensis* & 0.07 & 1 & & & & & & & & & & & 0.021 & & 0.014 \\
\hline Holothuria arenicola* & & & & & & & & & 0.08 & 1 & 0.1 & 1 & 0.021 & 0.042 & 0.028 \\
\hline Holothuria atra & 0.14 & 2 & & & 0.48 & 10 & 0.5 & 2 & & & 0.2 & 2 & 0.255 & 0.167 & 0.225 \\
\hline Holothuria difficilis* & & & & & 0.05 & 1 & & & 0.08 & 1 & & & 0.043 & & 0.028 \\
\hline Holothuria fuscocinerea* & & & & & 0.05 & 1 & & & 0.33 & 4 & & & 0.106 & & 0.070 \\
\hline Holothuria fuscogilva & & & & & 0.1 & 2 & & & & & & & 0.043 & & 0.028 \\
\hline Holothuria impatiens* & 0.07 & 1 & & & 0.1 & 2 & & & & & & & 0.064 & & 0.042 \\
\hline Holothuria hilla* & & & & & 0.1 & 2 & & & 0.17 & 2 & 0.1 & 1 & 0.085 & 0.042 & 0.070 \\
\hline Holothuria lineata & & & & & & & & & 0.08 & 1 & & & 0.021 & & 0.014 \\
\hline Holothuria nobilis & & & & & 0.33 & 7 & & & 0.58 & 8 & 0.3 & 3 & 0.319 & 0.125 & 0.254 \\
\hline Holothuria pardalis* & & & & & 0.05 & 1 & & & 0.25 & 3 & 0.2 & 2 & 0.085 & 0.083 & 0.085 \\
\hline Holothuria sp1 & & & & & 0.05 & 1 & & & & & & & 0.021 & & 0.014 \\
\hline Holothuria sp2 & & & & & & & 0.25 & 1 & & & & & & 0.042 & 0.014 \\
\hline Holothuria sp juvenile & & & & & & & & & & & 0.1 & 1 & & 0.042 & 0.014 \\
\hline Pearsonothuria graeffei & & & & & 0.14 & 3 & 0.5 & 2 & & & 0.2 & 1 & 0.064 & 0.125 & 0.085 \\
\hline \multicolumn{16}{|l|}{ Family Stichopodidae } \\
\hline Stichopus chloronotus & 0.29 & 4 & 0.1 & 1 & 0.38 & 8 & 0.5 & 2 & 0.08 & 1 & & & 0.277 & 0.125 & 0.225 \\
\hline Stichopus herrmanni* & & & & & 0.05 & 1 & & & & & & & 0.021 & & 0.014 \\
\hline Thelenota ananas & & & 0.1 & 1 & 0.33 & 7 & 0.75 & 3 & & & 0.2 & 2 & 0.149 & 0.250 & 0.183 \\
\hline Thelenota anax & & & & & 0.05 & 1 & & & & & & & 0.021 & & 0.014 \\
\hline \multicolumn{16}{|l|}{ Family Sclerodactylidae } \\
\hline Afrocucumis africana* & & & & & & & & & 0.08 & 1 & & & 0.021 & & 0.014 \\
\hline \multicolumn{16}{|l|}{ Family Synaptidae } \\
\hline Euapta godeffroyi & & & & & & & & & 0.08 & 1 & & & 0.021 & & 0.014 \\
\hline Synapta maculata & & & & & & & & & 0.17 & 4 & & & 0.085 & & 0.056 \\
\hline Patinapta sp. & 0.08 & 1 & & & & & & & & & & & 0.021 & & 0.014 \\
\hline \multicolumn{16}{|l|}{ Family Chiridotidae } \\
\hline Chiridota stuhlmani* & & & & & & & & & & & 0.1 & 1 & & 0.042 & 0.014 \\
\hline
\end{tabular}

confused with Ophiocoma brevipes).

The Asteroidea were represented by 6 families (Table 4). The Acanthasteridae were only represented by Acanthaster planci which ranked 3rd in occurrence; it was not found during BioReCIE at Europa where it had been seen previously (Quod et al., 2007), but outbreaks and disappearance of its populations are common; its occurrence was the greatest at Juan de Nova where it was recorded at 3 reef flat sites. The Asterinidae were only found at Europa and a new species Aquilonastra chantalae has been discovered (O'Loughlin and McKenzie, 2013; Conand et al., 2013). It is the only new echinoderm species from this programme, but some of the ophiuroid species may turn out to be currently unrecognized species (Hoareau et al., 2013). The Ophidiasteridae presented 3 species, including Linckia laevigata, with an occurrence of 0.17 , the highest for this class. The Goniasteridae was only represented by the infrequent species Neoferdina offreti. The Oreasteridae were represented by 2 species, Culcita schmiedeliana with an occurrence of 0.13 on the reef flats, and Choriaster granulatus found on 1 reef slope at the Glorieuses and 1 unidentified juvenile. The last family, Asteropseidae, was only represented on a reef flat at Juan de Nova (Mulochau et al. submitted for publication).

Finally nine species are considered as new records, from the results of BioReCIE (including the species presented in Conand et al., 2013 for Europa).
The Echinoidea were represented by 5 families of Regularia and 2 families of Irregularia (Table 5). The Cidaridae were represented by 3 species, with Eucidaris metularia found on reef flats and more frequently on slopes with a general occurrence of 0.14 . The Diadematidae, with 5 species, comprised a few juveniles that could not be identified at species level; Echinothrix calamaris was present on the 3 islands, on both reef habitats, with a general occurrence of 0.32. The Echinometridae were represented by 2 frequent and abundant species, Echinometra mathaei, mostly on reef flats, with a total occurrence of 0.23 and Echinostrephus molaris as the most frequent echinoid (0.42). Heterocentrotus mammillatus was found at Juan and Glorieuses. The Stomopneustidae and the Toxopneustidae were not observed at Europa and remain unfrequent on the whole. Only a few Irregularia from the Brissidae and Maretiidae families were observed.

Finally nine species are considered as new records, from the results of BioReCIE.

The Crinoidea were represented by 5 families (Table 6). They are usually more frequent on the reef slope habitats. The Mariametridae, with Stephanometra indica, a species found at the 3 islands, has the highest (but still rather low $<0.2$ ) occurrence. The other species still need a precise identification.

The five species are considered as new records, from the results of BioReCIE. 
Table 3

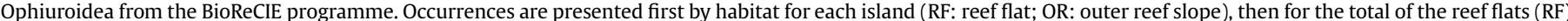

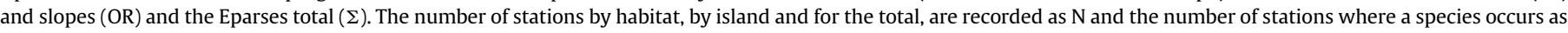
n. New records for Iles Eparses are marked by*.

\begin{tabular}{|c|c|c|c|c|c|c|c|c|c|c|c|c|c|c|c|}
\hline & \multicolumn{4}{|l|}{ Europa } & \multicolumn{4}{|c|}{ Juan de Nova } & \multicolumn{4}{|l|}{ Glorieuses } & \multicolumn{3}{|c|}{ Eparses (total) } \\
\hline & $\mathrm{RF} \mathrm{N}=14$ & $\mathrm{n}$ & OR $N=10$ & $\mathrm{n}$ & $\mathrm{RF} N=21$ & $\mathrm{n}$ & $\mathrm{OR} \mathrm{N}=4$ & $\mathrm{n}$ & $\mathrm{RF} N=12$ & $\mathrm{n}$ & OR $N=10$ & $\mathrm{n}$ & $\mathrm{RF} N=47$ & OR N $=24$ & $\Sigma N=71$ \\
\hline \multicolumn{16}{|l|}{ Family Ophiuridae } \\
\hline Ophiura kinbergi* & & & 0.1 & 1 & 0.04 & 1 & & & & & & & 0.021 & 0.042 & 0.028 \\
\hline \multicolumn{16}{|l|}{ Family Ophiodermatidae } \\
\hline Ophiarachnella gorgonia & & & & & 0.04 & 1 & & & 0.17 & 2 & & & 0.064 & & 0.042 \\
\hline Ophiopeza fallax* & & & & & & & 0.25 & 1 & & & 0.1 & 1 & & 0.083 & 0.028 \\
\hline \multicolumn{16}{|l|}{ Family Ophiocomidae } \\
\hline Ophiocoma brevipes & & & & & 0.24 & 6 & & & 0.75 & 9 & 0.1 & 1 & 0.319 & 0.042 & 0.225 \\
\hline Ophiocoma cynthiae & & & & & 0.12 & 3 & & & 0.92 & 11 & 0.2 & 2 & 0.298 & 0.083 & 0.225 \\
\hline Ophiocoma pica & & & & & & & & & 0.33 & 4 & 0.2 & 2 & 0.085 & 0.083 & 0.085 \\
\hline Ophiocoma cf. dentata* & & & & & & & & & 0.08 & 1 & 0.1 & 1 & 0.021 & 0.042 & 0.028 \\
\hline Ophiocoma cf. pusilla* & & & & & 0.04 & 1 & & & & & 0.1 & 1 & 0.021 & 0.042 & 0.028 \\
\hline Ophiocoma erinaceus & & & 0.2 & 2 & 0.12 & 3 & & & 0.33 & 4 & 0.8 & 8 & 0.149 & 0.417 & 0.239 \\
\hline Ophiocoma doederleini* & & & & & & & & & 0.08 & 1 & 0.1 & 1 & 0.021 & 0.042 & 0.028 \\
\hline Ophiocoma scolopendrina & 0.28 & 4 & & & & & & & 0.25 & 3 & & & 0.149 & 0.000 & 0.099 \\
\hline Ophiocoma valenciae & 0.08 & 1 & & & & & & & 0.08 & 1 & 0.1 & 1 & 0.043 & 0.042 & 0.042 \\
\hline Ophiomastix venosa & & & & & 0.04 & 1 & & & 0.42 & 5 & & & 0.128 & & 0.085 \\
\hline Ophiarthrum elegans* & & & & & & & & & 0.08 & 1 & 0.2 & 2 & 0.021 & 0.083 & 0.042 \\
\hline Ophiarthrum pictum & & & & & & & & & 0.17 & 2 & & & 0.043 & & 0.028 \\
\hline Ophiocomella sexradia* & 0.08 & 1 & & & & & & & & & & & 0.021 & & 0.014 \\
\hline \multicolumn{16}{|l|}{ Family Ophiotrichidae } \\
\hline Macrophiothrix longipeda & & & & & 0.2 & 5 & & & 0.17 & 2 & 0.6 & 6 & 0.149 & 0.250 & 0.183 \\
\hline Ophiothrix trilineata & & & 0.1 & 1 & & & & & & & 0.1 & 1 & & 0.083 & 0.028 \\
\hline Ophiothrix purpurea* & & & 0.5 & 5 & & & & & & & & & & 0.208 & 0.070 \\
\hline Ophiothela danae* & & & 0.6 & 6 & & & & & & & & & & 0.250 & 0.085 \\
\hline Ophiothela sp. & & & & & 0.04 & 1 & & & & & & & 0.021 & & 0.014 \\
\hline \multicolumn{16}{|l|}{ Family Ophiactidae } \\
\hline Ophiactis macrolepidota* & & & 0.2 & 2 & & & & & & & & & & 0.083 & 0.028 \\
\hline Ophiactis sp. & & & 0.1 & 1 & 0.04 & 1 & & & & & & & 0.021 & 0.042 & 0.028 \\
\hline Ophiactis savignyi* & 0.21 & 3 & & & 0.04 & 1 & & & & & & & 0.085 & & 0.056 \\
\hline \multicolumn{16}{|l|}{ Family Ophionereididae } \\
\hline Ophionereis dubia & & & & & & & 0.25 & 1 & & & & & & 0.042 & 0.014 \\
\hline Ophionereis sp. & & & & & 0.04 & 1 & & & & & & & 0.021 & & 0.014 \\
\hline Ophionereis porrecta & & & & & 0.08 & 2 & 0.25 & 1 & & & & & 0.043 & 0.042 & 0.042 \\
\hline \multicolumn{16}{|l|}{ Family Ophiolepididae } \\
\hline Ophiolepis cincta & & & & & & & & & 0.08 & 1 & & & 0.021 & & 0.014 \\
\hline Ophiolepis juv. & & & & & 0.04 & 1 & & & & & & & 0.021 & & 0.014 \\
\hline \multicolumn{16}{|l|}{ Family Amphiuridae } \\
\hline Amphipholis squamata* & 0.08 & 1 & & & & & & & & & & & 0.021 & & 0.014 \\
\hline Indet. black sp (cryptic) & & & 0.5 & 5 & & & & & & & & & & 0.208 & 0.070 \\
\hline
\end{tabular}

Table 4

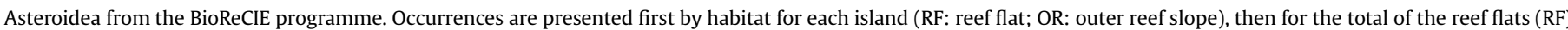

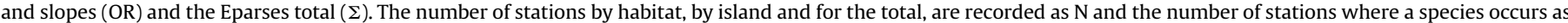
n. New records for Iles Eparses are marked by*.

\begin{tabular}{|c|c|c|c|c|c|c|c|c|c|c|c|c|c|c|c|}
\hline & \multicolumn{4}{|l|}{ Europa } & \multicolumn{4}{|c|}{ Juan de Nova } & \multicolumn{4}{|l|}{ Glorieuses } & \multicolumn{3}{|c|}{ Eparses (total) } \\
\hline & $\mathrm{RF} N=14$ & $\mathrm{n}$ & OR $N=10$ & $\mathrm{n}$ & $\mathrm{RF} N=21$ & $\mathrm{n}$ & $\mathrm{OR} \mathrm{N}=4$ & $\mathrm{n}$ & $\mathrm{RF} N=12$ & $\mathrm{n}$ & OR $N=10$ & $\mathrm{n}$ & $\mathrm{RF} N=47$ & $\mathrm{OR} N=24$ & $\Sigma \mathrm{N}=71$ \\
\hline \multicolumn{16}{|l|}{ Family Acanthasteridae } \\
\hline Acanthaster planci & & & & & 0.14 & 3 & 0.25 & 1 & 0.08 & 1 & & & 0.85 & 0.04 & 0.070 \\
\hline \multicolumn{16}{|l|}{ Family Asterinidae } \\
\hline Aquilonastra richmondi* & 0.08 & 1 & & & & & & & & & & & 0.021 & & 0.014 \\
\hline Aquilonastra chantalae new sp.* & 0.08 & 1 & & & & & & & & & & & 0.021 & & 0.014 \\
\hline \multicolumn{16}{|l|}{ Family Goniasteridae } \\
\hline Dactylosaster cylindricus* & & & & & 0.05 & 1 & & & 0.08 & 1 & & & 0.043 & & 0.028 \\
\hline Linckia laevigata* & 0.08 & 1 & & & 0.24 & 5 & & & 0.17 & 2 & 0.40 & 4 & 0.170 & 0.17 & 0.169 \\
\hline Linckia multifora* & & & & & 0.05 & 1 & & & 0.08 & 1 & & & 0.043 & & 0.028 \\
\hline \multicolumn{16}{|l|}{ Family Ophidiasteridae } \\
\hline Neoferdina offreti* & & & & & 0.05 & 1 & 0.5 & 2 & & & 0.10 & 1 & 0.021 & 0.13 & 0.056 \\
\hline \multicolumn{16}{|l|}{ Family Oreasteridae. } \\
\hline Culcita schmideliana* & & & & & 0.24 & 5 & & & 0.08 & 1 & & & 0.128 & & 0.085 \\
\hline Choriaster granulatus* & & & & & & & & & & & 0.10 & 1 & & 0.04 & 0.014 \\
\hline Oreasterid juv. & 0.08 & 1 & & & & & & & & & & & 0.021 & & 0.014 \\
\hline \multicolumn{16}{|l|}{ Family Asteropseidae } \\
\hline Asteropsis carinifera* & & & & & 0.05 & 1 & & & & & & & 0.021 & & 0.014 \\
\hline
\end{tabular}


Table 5

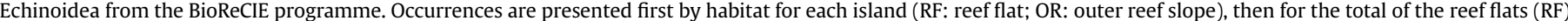

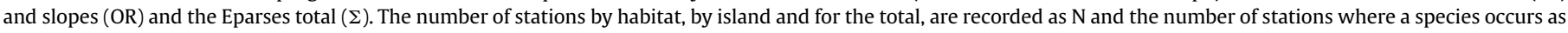
n. New records for Iles Eparses are marked by*.

\begin{tabular}{|c|c|c|c|c|c|c|c|c|c|c|c|c|c|c|c|}
\hline & \multicolumn{4}{|l|}{ Europa } & \multicolumn{4}{|c|}{ Juan de Nova } & \multicolumn{4}{|l|}{ Glorieuses } & \multicolumn{3}{|c|}{ Eparses (total) } \\
\hline & $\mathrm{RF} N=14$ & $\mathrm{n}$ & $\mathrm{OR} N=10$ & $\mathrm{n}$ & $\mathrm{RF} N=21$ & $\mathrm{n}$ & $\mathrm{OR} \mathrm{N}=4$ & $\mathrm{n}$ & $\mathrm{RF} N=12$ & $\mathrm{n}$ & OR $N=10$ & $\mathrm{n}$ & $\mathrm{RF} N=47$ & OR N $=24$ & $\Sigma N=71$ \\
\hline \multicolumn{16}{|l|}{ Family Cidaridae } \\
\hline Plococidaris verticillata* & & & & & 0.05 & 1 & & & & & & & 0.021 & & 0.014 \\
\hline Prionocidaris pistillaris* & & & & & & & 0.25 & 1 & & & & & & 0.042 & 0.014 \\
\hline Eucidaris metularia & 0.16 & 2 & 0.1 & 1 & 0.1 & 2 & 0.25 & 1 & & & 0.4 & 4 & 0.085 & 0.250 & 0.141 \\
\hline \multicolumn{16}{|l|}{ Family Diadematidae } \\
\hline Diadema savignyi* & 0.08 & 1 & 0.1 & 1 & & & & & & & & & 0.021 & 0.042 & 0.028 \\
\hline Diadema sp. & 0.25 & 3 & 0.1 & 1 & & & & & & & & & 0.064 & 0.042 & 0.056 \\
\hline Echinothrix calamaris* & & & 0.1 & 1 & 0.38 & 8 & 0.25 & 1 & 0.67 & 8 & 0.5 & 5 & 0.340 & 0.292 & 0.324 \\
\hline Echinothrix diadema* & 0.25 & 3 & & & 0.1 & 2 & & & & & & & 0.106 & & 0.070 \\
\hline Echinothrix sp. & & & 0.3 & 3 & & & & & & & & & & 0.125 & 0.042 \\
\hline \multicolumn{16}{|l|}{ Family Echinometridae } \\
\hline Echinometra mathaei & 0.58 & 8 & 0.2 & 2 & 0.05 & 1 & & & 0.42 & 5 & & & 0.298 & 0.083 & 0.225 \\
\hline Echinostrephus molaris & 0.33 & 3 & 0.5 & 5 & 0.48 & 10 & 1 & 4 & 0.33 & 4 & 0.9 & 4 & 0.362 & 0.542 & 0.423 \\
\hline Heterocentrotus mammillatus* & & & & & & & 0.25 & 1 & & & 0.4 & 4 & & 0.208 & 0.070 \\
\hline \multicolumn{16}{|l|}{ Family Stomopneustidae } \\
\hline Stomopneustes variolaris* & & & & & 0.1 & 2 & & & 0.17 & 2 & & & 0.085 & & 0.056 \\
\hline \multicolumn{16}{|l|}{ Family Toxopneustidae } \\
\hline Toxopneustes pileolus & & & & & & & & & & & 0.1 & 1 & & 0.042 & 0.014 \\
\hline \multicolumn{16}{|l|}{ Family Brissidae } \\
\hline Brissus latecarinatus* & & & & & & & & & 0.08 & 1 & 0.1 & 1 & 0.021 & 0.042 & 0.028 \\
\hline Metalia spatangus* & & & & & 0.05 & 1 & & & & & & & 0.021 & & 0.014 \\
\hline \multicolumn{16}{|l|}{ Maretiidae } \\
\hline Maretia planulata* & & & & & & & & & & & 0.2 & 2 & & 0.083 & 0.028 \\
\hline
\end{tabular}

\section{Discussion}

The programme BioReCIE has allowed the first synthesis on the diversity of the five classes of the phylum Echinodermata, in the Iles Eparses of the Mozambique Channel (Europa, Juan de Nova and Glorieuses, from South to North). In total, about 100 species are present, with 31 Holothuroidea, 31 Ophiuroidea, 13 Asteroidea, 16 Echinoidea and 9 Crinoidea, with several not yet identified at the species level. A more precise identification will be needed in the future. One new species, Aquilonastra chantalae, has been described so far (O'Loughlin and McKenzie, 2013) and several new records are reported for each class, as these islands had previously received little attention.

At the scale of the WIO, these results are compared with the number of species recorded by class, presented and illustrated for the most common ones, in the chapter 'Phylum Echinodermata' by Rowe and Richmond (2011) on Eastern Africa and the Western Indian Ocean Islands, as this is a recent synthesis on this phylum presently available: 140 Holothuroidea (45 presented, 30 illustrated), 130 Ophiuroidea (80 presented, 24 illustrated), 60 Asteroidea (52 presented, 30 illustrated), 60 Echinoidea (45 recorded, 30 illustrated) and 20 Crinoidea (17 presented, 6 illustrated). Our results from the BioReCIE programme, limited to 3 coral islands, bring roughly the same proportions for the different classes, showing the dominance of Holothuroidea and Ophiuroidea.

The total diversity of echinoderms is higher in the north of the Mozambique Channel (Glorieuses and Juan de Nova) compared to the south of the channel (Europa). This pattern is also described for scleractinians by Obura (2012) who described the north of the

Table 6

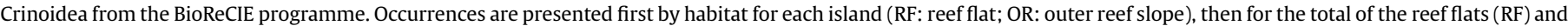

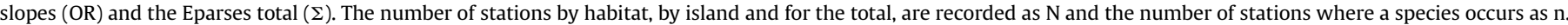
New records for Iles Eparses are marked by*.

\begin{tabular}{|c|c|c|c|c|c|c|c|c|c|c|c|c|c|c|c|}
\hline & \multicolumn{4}{|l|}{ Europa } & \multicolumn{4}{|c|}{ Juan de Nova } & \multicolumn{4}{|l|}{ Glorieuses } & \multicolumn{3}{|c|}{ Eparses (total) } \\
\hline & $\mathrm{RF} N=14$ & $\mathrm{n}$ & $\mathrm{OR} N=10$ & $\mathrm{n}$ & $\mathrm{RF} N=21$ & $\mathrm{n}$ & $\mathrm{OR} \mathrm{N}=4$ & $\mathrm{n}$ & $\mathrm{RF} N=12$ & $\mathrm{n}$ & $\mathrm{OR} N=10$ & $\mathrm{n}$ & $\mathrm{RF} N=47$ & OR $N=24$ & $\Sigma \mathrm{N}=71$ \\
\hline Family Mariametridae & & & & & & & & & & & & & & & \\
\hline $\begin{array}{l}\text { Stephanometra indica* } \\
\text { Family Comatulidae }\end{array}$ & & & 0.2 & 2 & 0.25 & 1 & & & 0.1 & 1 & & & 0.021 & 0.125 & 0.056 \\
\hline $\begin{array}{l}\text { cf Comanthus whalbergii* } \\
\text { Family Tropiometridae }\end{array}$ & 0.16 & 2 & 0.1 & 1 & 0.1 & 2 & 0.25 & 1 & & & 0.4 & 4 & 0.085 & 0.250 & 0.141 \\
\hline $\begin{array}{l}\text { Tropiometra cf carinata* } \\
\text { Family Colobometridae }\end{array}$ & 0.08 & 1 & 0.1 & 1 & & & & & & & & & 0.021 & 0.042 & 0.042 \\
\hline $\begin{array}{l}\text { Cenometra bella* } \\
\text { Family Antedonidae }\end{array}$ & & & 0.1 & 1 & 0.04 & 1 & & & & & & & 0.021 & 0.04 & 0.028 \\
\hline Dorometra cf aegyptica* & & & 0.1 & 1 & & & & & & & & & & 0.04 & 0.014 \\
\hline Dorometra sp. & & & & & & & & & & & 0.1 & 1 & & 0.04 & 0.014 \\
\hline Antedonidae indet & & & & & & & 0.25 & 1 & & & & & & 0.04 & 0.014 \\
\hline crinoidea indet sp 1 & & & & & 0.4 & 1 & & & & & & & 0.21 & & 0.014 \\
\hline crinoidea indet sp 2 & & & & & & & 0.25 & 1 & & & & & & 0.04 & 0.014 \\
\hline
\end{tabular}


Mozambique Channel as the "coral triangle of the Indian Ocean". This pattern could be due to currents, which favour connectivity between coral reef populations in this region. As for other sites, the species richness of Echinodermata is low compared to fishes (Chabanet et al., 2014a) or Decapoda crustaceans which comprise 175 species in Europa, 157 in Glorieuse and 109 in Juan (Poupin, submitted).

Among the five classes, the Holothuroidea, given the increasing commercial value of several species (Conand, 2004, 2006, 2008), have received more attention, with several local studies in the Comoros (Samyn et al., 2006), Madagascar (Cherbonnier, 1988), Mayotte (Pouget, 2005; Eriksson et al., 2012), or La Reunion (Conand et al., 2010), and more generally in this region of the WIO (Samyn and Tallon, 2005; Conand and Muthiga, 2007; Conand, 2008; Muthiga and Conand, 2014; Eriksson et al., 2015).

The systematic and classification of the Ophiuroidea are presently being reviewed, both with genetics and morphology (Thuy \& Stöhr in prep; Hoareau et al., 2013; O'Hara et al., 2014; O'Hara et al. in prep.) and changes at all taxonomic levels are expected. Most of the observed species are common tropical shallow water species previously reported from the Indian Ocean, the Indo-Pacific, and nearby islands such as La Réunion (Clark and Rowe, 1971; Stöhr et al., 2008).

In Asteroidea, the populations of Acanthaster planci deserve special attention, given the dynamic of their outbreaks. They have for example recently been studied in Mayotte (UICN, 2014) and should be monitored in the Iles Eparses.

The Echinoidea present large populations of common species on the reef flats, as generally observed in the tropics, but additional collecting efforts remain necessary to evaluate the diversity of the cryptic and infaunal species.

The Crinoidea constitute large populations mostly observed on the exposed reef slopes, a feature that may be linked to current flow requirement for basic physiological functions such as feeding. Their diversity is probably underestimated, as some species, such as Stephanometra indica and Tropiometra carinata may constitute complexes (in Mulochau et al. in revision). The Crinoidea collected during the BioReCIE program are attributed to five families, four of which are closely related, whereas the family Antedonidae is illdefined. The class Crinoidea is undergoing a complete revision at all levels of the taxonomy.

Illegal fisheries are an important problem which needs new tools to be documented and managed carefully. Among echinoderms, holothurians are of strong concern as a highly priced commodity, overexploited in many countries for export of the dried product Bêche-de-mer (or trepang), consumed by Asiatic populations (Conand, 2004, 2006, 2008; Toral-Granda et al., 2008; Purcell et al., 2013). Illegal, Unreported and Unregulated (IUU) fishing activities have received increasing attention, at both national and international levels, since the first FAO report (FAO, 2001), and the number of recent multidisciplinary (concerning environment and society) publications in the fishery literature is growing, because IUU undermine management efforts and conservation success (Le Gallic, 2007; Osterblom, 2014). The smallscale fisheries of sea cucumbers have a very long history, mostly in tropical regions where poaching has long been reported. In the WIO it is unfortunately also a recurrent practice, as noted for several countries where the regulations and their enforcement are weak (Conand, 2008; Conand et al., 2014; Eriksson et al., 2015). Despite the apparent abundance of commercial species recorded during this project, the question of the illegal fishery must be considered. Seizures within the Exclusive Economic Zone (EEZ) of the Iles Eparses were done in 2013 and again 2014, when foreign vessels with diving gear and one tonne of holothurians preserved in salt were arrested by the French authorities (TAAF, 2014) Other indirect evidence is also coming from this programme, as during the 2012 fieldtrip in Glorieuses, the white teatfish H. fuscogilva, a highly valuable species previously observed, was not found again, which might be attributable to poaching (Conand et al., 2014). The need for better protection of these resources in the Iles Eparses has been stressed. Illegal catches (quantity and species specific records) will be documented by the French authorities and the species abundance in the natural habitat should be monitored. International collaboration will also be very useful to better fight IUU.

Comparison with the synthetic results on the other taxonomic groups, from this programme BioReCIE, and from other studies in the Eparses and the WIO will later allow a more detailed analysis of the general characteristics of the habitats and their flora and fauna.

Additional sampling in the Iles Eparses is needed to properly compare the coral reef fauna between the islands over time, to conserve and protect the biodiversity of these remote and relatively pristine areas.

\section{Disclosure}

Chantal Conand has participated in the Europa fieldtrip, identified the holothurians and wrote the draft manuscript. And approves the final text.

Thierry Mulochau has participated in the Glorieuses and Juan fieldtrips, collected and identified some echinoderms. And approves the final text.

Marc Eléaume has identified the Crinoidea. And approves the final text.

Sabine Stöhr has identified the Ophiuroidea and contributed to writing the article. And approves the final text.

Pascale Chabanet has organised the programme, participated in the fieldtrips and contributed to the writing. And approves the final text.

\section{Acknowledgements}

We would like to thank the administration of the TAAF for research permits and financial support; the 'Forces Armées de la Zone Sud de l'océan Indien' (FAZSOI) for logistic support. Financial support for the expeditions was provided by the Institut Ecologie et Environnement du Centre National pour la Recherche (INEECNRS), the Institut National des Sciences de l'Univers (INSU), the Institut de Recherche pour le Développement (IRD), the Fondation pour la Recherche sur la Biodiversité (FRB), the Agence des Aires Marines Protégées (AAMP) and the Veolia Environment Foundation.

We are thankful to all the participants of the BioReCIE campains for their help in collection of specimens, observations and photos. The help of S. Coppard, H. Lessios and C. de Ridder with the identification of some echinoids, C. Mah and $M$. O'Loughlin with asteroids, E. Boissin and T Hoareau with ophiuroids has been very valuable. An early version has greatly benefited from the comments of the anonymous reviewers and the editors. 


\section{Appendix A}

Table A.1

Station list for Echinodermata observed at Europa during BioReCIE (Conand et al., 2013).

\begin{tabular}{|c|c|c|c|c|c|}
\hline Dates & Stations & Habitat & Latitude (S) & Longitude (E) & Depth (m)) \\
\hline 07/11/2011 & dive 1 (EU7) & Outer slope & -22.32943 & 40.36508 & $9-12 \mathrm{~m}$ \\
\hline $08 / 11 / 2011$ & dive 2 (EU6) & Outer slope & -22.34063 & 40.33716 & $8-10 \mathrm{~m}$ \\
\hline $09 / 11 / 2011$ & dive 3 (EU3) & Outer slope & -22.37300 & 40.32483 & $11-13 \mathrm{~m}$ \\
\hline $09 / 11 / 2011$ & dive 4 (EU4) & Outer slope & -22.4040 & 40.3702 & $12 \mathrm{~m}$ \\
\hline $10 / 11 / 2011$ & dive 5 (BIO8) & Outer slope & -22.3853 & 40.3885 & $11 \mathrm{~m}$ \\
\hline $10 / 11 / 2011$ & dive 6 (EU2) & Outer slope & -22.3529 & 40.3967 & $13 \mathrm{~m}$ \\
\hline $11 / 11 / 2011$ & dive 7 (BIO14) & Outer slope & -22.3590 & 40.3296 & $12 \mathrm{~m}$ \\
\hline $11 / 11 / 2011$ & dive 8 (BIO5) & Outer slope & -22.3840 & 40.375 & $10 \mathrm{~m}$ \\
\hline $12 / 11 / 2011$ & dive 9 (BIO12) & Outer slope & -22.3353 & 40.3889 & $10 \mathrm{~m}$ \\
\hline $13 / 11 / 2011$ & dive 10 (EU5) & Reef front & -22.3412 & 40.3376 & $3 \mathrm{~m}$ \\
\hline $07 / 11 / 2011$ & St 1 (Pl1) & Reef flat & -22.3400 & 40.3461 & 0.5 \\
\hline $07 / 11 / 2011$ & St 3 & Reef flat & -22.3395 & 40.3641 & 0.5 \\
\hline $08 / 11 / 2011$ & St 4 (BIO28) & Reef flat & -22.3596 & 40.3310 & 0.5 \\
\hline $08 / 11 / 2011$ & St 5 & Reef flat & -22.3484 & 40.3314 & 0.5 \\
\hline $08 / 11 / 2011$ & St 6 & Reef flat & -22.3431 & 40.3819 & 2 \\
\hline $08 / 11 / 2011$ & St $6 A$ & Mangrove & -22.3395 & 40.3641 & 0.5 \\
\hline 09/11/2011 & St 8 (B34) & Reef flat & -22.3448 & 40.3676 & 0.5 \\
\hline $09 / 11 / 2011$ & St $8 \mathrm{~A}(\mathrm{CC})$ & Reef flat & & & 0.5 \\
\hline $09 / 11 / 2011$ & St 9 & Mangrove & -22.3489 & 40.3708 & 0.5 \\
\hline $10 / 11 / 2011$ & St 10 & Mangrove & -22.3431 & 40.3819 & 0.5 \\
\hline $10 / 11 / 2011$ & St 11 (BIO116) & Lagon-mangrove & -22.3364 & 40.3837 & 0.5 \\
\hline $10 / 11 / 2011$ & St $11 \mathrm{~A}(\mathrm{CC})$ & Reef flat & & & 0.5 \\
\hline $11 / 11 / 2011$ & St 14 & Lagon-mangrove & -22.3565 & 40.3912 & 0.5 \\
\hline $12 / 11 / 2011$ & St 15 (BIO25) & Reef flat & -22.3953 & 40.3767 & 0.5 \\
\hline
\end{tabular}

Table A.2

Station list for Echinodermata observed at Glorieuses during BioReCIE (Conand et al., 2014).

\begin{tabular}{|c|c|c|c|c|c|}
\hline Dates & Stations & Habitat & Latitude (S) & Longitude (E) & Depth $(\mathrm{m}))$ \\
\hline $07 / 12 / 2012$ & 27 & Reef flat & -1134134 & 47.17384 & 2.5 \\
\hline $07 / 12 / 2012$ & 28 & Reef flat & -1134.128 & 47.17560 & 2 \\
\hline $07 / 12 / 2012$ & 31 & Reef flat & -11.34981 & 47.17111 & 0.5 \\
\hline $07 / 12 / 2012$ & 32 & Reef flat & -11.35129 & 47.17346 & 0.5 \\
\hline $07 / 12 / 2012$ & 33 & Reef flat & -11.34851 & 47.17126 & 0.5 \\
\hline $08 / 12 / 2012$ & 29 & Reef flat & $-11.35417^{\prime}$ & 47.18191 & 0.5 \\
\hline $08 / 12 / 2012$ & 30 & Reef flat & $-11.35217^{\prime}$ & 47.18406 & 0.5 \\
\hline $09 / 12 / 2012$ & GLO 6 & Reef slope & -11.32973 & 47.17755 & 13 \\
\hline $09 / 12 / 2012$ & GLO 2 & Reef slope & -11.34880 & 47.16862 & 10 \\
\hline $10 / 12 / 2012$ & 16 & Reef slope & -11.35122 & 47.20091 & 12 \\
\hline $10 / 12 / 2012$ & 17 & Reef slope & -11.35804 & 47.18524 & 9 \\
\hline $11 / 12 / 2012$ & 18 & Reef slope & -11.32067 & 47.24273 & 10 \\
\hline $11 / 12 / 2012$ & GLO 3 & Reef slope & -11.33625 & 47.22447 & 13 \\
\hline $12 / 12 / 2012$ & 19 & Reef flat & -11.30505 & 47.22560 & 4 \\
\hline $12 / 12 / 2012$ & 20 & Reef slope & -11.30785 & 47.21712 & 11 \\
\hline $12 / 12 / 2012$ & GLO 7 & Inner slope & -11.32227 & 47.22402 & 4 \\
\hline $13 / 12 / 2012$ & 36 & Reef flat & -11.30869 & 47.22759 & 0.5 \\
\hline $13 / 12 / 2012$ & 37 & Reef flat & -11.30899 & 47.22512 & 0.5 \\
\hline $14 / 12 / 2012$ & GLO 5 & Inner slope & -11.32388 & 47.20458 & 6 \\
\hline $14 / 12 / 2012$ & GLO 1 & Reef slope & -11.33673 & 47.17474 & 11 \\
\hline $15 / 12 / 2012$ & 22 & Reef flat & -11.34214 & 47.19833 & 0.5 \\
\hline $15 / 12 / 2012$ & 23 & Reef flat & -11.34334 & 47.20003 & 0.5 \\
\hline
\end{tabular}


Table A.3

Station list for Echinodermata observed at Juan during BioReCIE (Mulochau et al. in revision).

\begin{tabular}{|c|c|c|c|c|c|}
\hline Dates & Stations & Habitat & Latitude (S) & Longitude (E) & Depth (m) \\
\hline $07 / 12 / 2013$ & St 20 & Lagoon reef patch & -17.03259 & 42.73574 & 1 \\
\hline $07 / 12 / 2013$ & St 52 & Lagoon reef patch & -17.03712 & 42.72429 & 1 \\
\hline $08 / 12 / 2013$ & St 2 & Reef flat & -17.06136 & 42.71416 & 0.5 \\
\hline $09 / 12 / 2013$ & St 3 & Reef flat & -17.07019 & 42.71046 & 0.5 \\
\hline $09 / 12 / 2013$ & St 86 & Lagoon reef patch & -17.01781 & 42.71705 & 1 \\
\hline $10 / 12 / 2013$ & St 25 & Lagoon reef patch & -16.95350 & 42.75982 & 1 \\
\hline $11 / 12 / 2013$ & St 117 & Lagoon reef patch & -17.02772 & 42.72481 & 1 \\
\hline $11 / 12 / 2013$ & St 27 & Outer slope & -17.08177 & 42.72536 & 5.0 \\
\hline $12 / 12 / 2013$ & St 8 & Reef flat & -17.05806 & 42.69461 & 0.5 \\
\hline $12 / 12 / 2013$ & St 28 & Lagoon reef patch & -17.01960 & 42.68127 & 1 \\
\hline $12 / 12 / 2013$ & St 29 & Outer slope & -17.05418 & 42.67435 & 5.0 \\
\hline $13 / 12 / 2013$ & St 10 & Reef flat & -17.04569 & 42.68039 & 0.5 \\
\hline $13 / 12 / 2013$ & St 30 & Lagoon reef patch & -16.96562 & 42.69472 & 1 \\
\hline $13 / 12 / 2013$ & St 31 & Lagoon reef patch & -16.94298 & 42.70940 & 1 \\
\hline $14 / 12 / 2013$ & St 11 & Reef flat & -17.04231 & 42.69587 & 0.5 \\
\hline $14 / 12 / 2013$ & St 33 & Outer slope & -17.01507 & 42.65688 & 5 \\
\hline $14 / 12 / 2013$ & St 140 & Outer slope & -17.01493 & 42.65645 & 5 \\
\hline $14 / 12 / 2013$ & St 144 & Reef flat & -17.02939 & 42.68913 & 0.5 \\
\hline $15 / 12 / 2013$ & St 14 & Reef flat & -17.03932 & 42.73068 & 0.5 \\
\hline $15 / 12 / 2013$ & St 15 & Reef flat & -17.04192 & 42.71683 & 0.5 \\
\hline $15 / 12 / 2013$ & St 34 & Outer slope & -17.01076 & 42.80413 & 5 \\
\hline $15 / 12 / 2013$ & St 35 & Outer slope & -17.07472 & 42.76651 & 5 \\
\hline $15 / 12 / 2013$ & St 165 & Reef flat & -17.05728 & 42.77669 & 0.5 \\
\hline $16 / 12 / 2013$ & St 16 & Reef flat & -17.05087 & 42.68053 & 0.5 \\
\hline $16 / 12 / 2013$ & St 17 & Reef flat & -17.04783 & 42.68040 & 0.5 \\
\hline $16 / 12 / 2013$ & St 37 & Reef flat & -17.03573 & 42.68453 & 0.5 \\
\hline $17 / 12 / 2013$ & St 38 & Lagoon reef patch & -17.03507 & 42.77117 & 2 \\
\hline $17 / 12 / 2013$ & St 196 & Lagoon reef patch & -17.03056 & 42.75651 & 2 \\
\hline
\end{tabular}

\section{References}

Boxshall, G.A., Mees, J., Costello, M.J., Hernandez, F., Gofas, S., Hoeksema, B.W., Klautau, M., Kroh, A., Paulay, G., Poore, G., Read, G.B., Stöhr, S., de Voogd, N., De Broyer, C., Horton, T., Kennedy, M., Decock, W., Dekeyzer, S., Trias Verbeeck, A., Vandepitte, L., Vanhoorne, B., Adams, M.J., Adlard, R., Adriaens, P., Agatha, S., Ahn, K.J., Ahyong, S., Alvarez, B., Alvarez, F., Anderson, G., Angel, M., Artois, T., Bail, P., Bailly, N., Bamber, R., Barber, A., Bartsch, I., Bellan-Santini, D., Berta, A., Bieler, R., Bitner, M.A., Błażewicz-Paszkowycz, M., Bock, P., Böttger-Schnack, R., Bouchet, P., Boury-Esnault, N., Boyko, C., Brandão, S.N., Bray, R., Bruce, N.L., Caballer, M., Cairns, S., Cárdenas, P., Carrera-Parra, L.F., Carstens, E., Catalano, S., Cedhagen, T., Chan, B.K., Chan, T.Y., Cheng, L., Churchill, M., Coleman, C.O., Collins, A.G., Crandall, K.A., Cribb, T., Dahdouh-Guebas, F., Daneliya, M., Dauvin, J.C., Davie, P., Dayrat, B., De Grave, S., d'Hondt, J.L., Díaz, M.C., Dijkstra, H., Dohrmann, M., Dolan, J., Doner, S., Eibye-Jacobsen, D., Eitel, M., Emig, C., Epler, J., Faber, M., Fauchald, K., Fautin, D., Feist, S., FernándezRodríguez, V., Fišer, C., Foster, W., Frank, J.H., Fransen, C., Fraussen, K., Furuya, H., Garcia-Alvarez, O., Gasca, R., Gaviria-Melo, S., Gerken, S., Gheerardyn, H., Gibson, D., Gil, J., Gittenberger, A., Glasby, C., Glover, A., González Solís, D., Gordon, D., Grabowski, M., Guerra-García, J.M., Guiry, M.D., Hajdu, E., Hallermann, J., Harasewych, J., Harris, L., Hayward, B., Hendrycks, E., Ho, J. s., Høeg, J., Holsinger, J., Hooper, J., Houart, R., Hughes, L., Hummon, W., Iseto, T., Ivanenko, S., Janussen, D., Jarms, G., Jazdzewski, K., Just, J., Kamaltynov, R.M., Kaminski, M., Kantor, Y., Karanovic, I., Kelly, M., Kim, Y.H., King, R., Kirk, P., Kolb, J., Krapp-Schickel, T., Kremenetskaia, A., Krijnen, C., Kristensen, R., Kronenberg, G., Krylova, E., LaFollette, P., Lambert, G., Lazarus, D., LeCroy, S., Lefkowitz, E.J., Lemaitre, R., Lester, B., Londoño Mesa, M.H., Lowry, J., Macpherson, E., Madin, L., Mah, C., Manconi, R., Mapstone, G., Marshall, B., Marshall, D.J., Meland, K., Merrin, K., Messing, C., Mills, C., Molodtsova, T., Monsecour, K., Mooi, R., Moreira da Rocha, R., Moretzsohn, F., Mortimer, J., Nealova, L., Neubauer, T.A., Neuhaus, B., Ng, P., Nielsen, C., Nishikawa, T., Norenburg, J., O'Hara, T., Oliverio, M., Opresko, D., Osawa, M., Parker, A., Patterson, D., Paxton, H., Peñas, A., Perrier, V., Perrin, W., Pilger, J.F., Pisera, A., Polhemus, D., Pugh, P., Reid, D.G., Reimer, J.D., Reuscher, M., Rius, M., Robin, A., Rolán, E., Rosenberg, G., Rützler, K., Rzhavsky, A., Saiz-Salinas, J., SalazarVallejo, S., Sames, B., Sartori, A.F., Satoh, A., Scarabino, V., Schatz, H., Schierwater, B., Schmidt-Rhaesa, A., Schneider, S., Schönberg, C., Schotte, M. Schuchert, P., Segers, H., Self-Sullivan, C., Senna, A.R., Serejo, C., Shamsi, S., Shenkar, N., Siegel, V., Sinniger, F., Sivell, D., Sket, B., Smit, H., Staples, D., Sterrer, W., Stienen, E., Suárez-Morales, E., Summers, M., Suttle, C., Swalla, B.J., Tabachnick, K.R., Taiti, S., Tang, D., Tasker, M., Taylor, J., Tëmkin, I., ten Hove, H., ter Poorten, J.J., Terryn, Y., Thomas, J., Thuesen, E.V., Thurston, M., Thuy, B. Timi, J.T., Timm, T., Todaro, A., Tucker, J., Turon, X., Tyler, S., Uetz, P., Vacelet, J., Vader, W., Väinölä, R., van der Meij, S.E., van Ofwegen, L., van Soest, R., Van Syoc, R., Vanaverbeke, J., Vervaet, F., von Cosel, R., Vonk, R., Vos, C., WalkerSmith, G., Walter, T.C., Watling, L., White, K., Whitmore, D., Williams, G., Wilson, G.D., Wyatt, N., Wylezich, C., Yasuhara, M., Zanol, J., Zeidler, W., 2014.
World Register of Marine Species. Available from: http://www.marinespecies. org. at VLIZ. Accessed 2014

Chabanet, P., Bigot, L., Bourmaud, A.-F., Cavailles, G., Conand, C., Durville, P., GravierBonnet, N., Mattio, L., Mulochau, T., Magalon, H., Nicet, J.-B., Obura, D., Poupin, J. Zubia, M., 2013. Assessing coral reef biodiversity at the Glorieuses Islands Marine park (Scattered Islands, SW Indian Ocean) with identification of priority zones for conservation. In: 8th WIOMSA Symposium, Maputo (Abstract).

Chabanet, P., Andrefouet, S., Bigot, L., Bourmaud, A.-F., Conand, C., Durville, P., Fricke, R., Gravier-Bonnet, N., Mattio, L., Mulochau, T., Magalon, H., Nicet, J.-B. Obura, D., Poupin, J., Russo, C., Tessier, E., Zubia, M., 2014a. Biodiversité Ressources et Conservation des récifs coralliens des Iles Eparses. P., Andrefouet 2014. BIORECIE. Colloque Iles Eparses, Paris (abstract).

Chabanet, P., Bigot, L., Nicet, J.-B., Durville, P., Mulochau, T., Obura, D., Massé, L. Russo, C., Tessier, E., 2014b. Coral Reef Monitoring in the Iles Eparses Mozambique Channel (2011-2013) Using GCRMN Methods. Acta Oecologica submitted for publication.

Cherbonnier, G., 1988. Echinodermes : Holothuries. Faune de Madagascar, p. 292, 70, ORSTOM, Paris.

Cherbonnier, G., Guille, A., 1978. Echinodermes: Ophiurides. Faune de Madagascar, p. 272, 48, Centre National de la Recherche Scientifique, Paris.

Clark, A.M., Rowe, F.W.E., 1971. Monograph of Shallow-water Indo-west Pacific Echinoderms. Trustees of the British Museum (Natural History), London.

Clark, A.M., 1980. Some Ophiuroidea from the Seychelles islands and Inhaca, Mozambique (Echinodermata). Rev. Zool. Afr. 94 (3), 533-558.

Conand, C., 2004. Present status of world sea cucumber resources and utilisation: an international overview: 13-23. In: Lovatelli, A., Conand, C., Purcell, S. Uthicke, S., Hamel, J.-F., Mercier, A. (Eds.), Advances in Sea Cucumber Aquaculture and Management, p. 425. FAO Fisheries Technical Paper No. 463.

Conand, C., 2006. Harvest and trade: utilization of sea cucumbers; sea cucumber fisheries; current international trade; illegal, unreported and unregulated trade; bycatch; socio-economic characteristics of the trade in sea cucumbers: 51-73. In: Bruckner, A.W. (Ed.), The Proceedings of the CITES Workshop on the Conservation of Sea Cucumbers in the Families Holothuriidae and Stichopodidae. NOAA Technical Memorandum, p. 244.

Conand, C., 2008. Population status, fisheries and trade of sea cucumbers in Africa and Indian ocean 153-205. In: Toral-Granda, V., Lovatelli, A., Vasconcellos, M. (Eds.), Sea Cucumbers. A Global Review on Fishery and Trade, p. 319. FAO Fisheries Technical Paper. No. 516. Rome, FAO. 2008.

Conand, C., Muthiga, N., 2007. WIOMSA Book Series No. 5. In: . Commercial Sea Cucumbers: a Review for the Western Indian Ocean, p. 66.

Conand, C., Michonneau, F., Paulay, G., Bruggemann, H., 2010. Diversity of the holothuroid fauna (Echinodermata) in La Réunion (Western Indian Ocean). West. Indian Ocean J. Mar. Sci. 9 (2), 145-151.

Conand, C., Stöhr, S., Eleaume, M., Magalon, H., Chabanet, P., 2013. The echinoderm fauna of Europa, Eparses island, (Scattered islands) in the Mozambique Channel (South western Indian Ocean). Cah. Biol. Mar. 54, 499-504.

Conand, C., Mulochau, T., Chabanet, P., 2014. The holothurian (Echinodermata) 
biodiversity of the Glorieuses islands (Eparses islands, France, Mozambique Channel). West. Indian Ocean J. Mar. Sci. 12 (1), 71-78.

Eriksson, H., Byrne, M., de la Torre-Castro, M., 2012. Sea cucumber (Aspidochirotida) community, distribution and habitat utilization on the reefs of Mayotte, Western Indian Ocean. Mar. Ecol. Prog. Ser 452, 159-170.

Eriksson, H., Conand, C., Lovatelli, A., Muthiga, N., Purcell, S., 2015. Governance structures and sustainability in Indian Ocean sea cucumber fisheries. Mar. Policy 56, 16-22.

FAO, 2001. International Plan of Action to Prevent, Deter and Eliminate Illegal, Unreported and Unregulated Fishing. FAO, Rome.

FAO, 2013. Report on the FAO Workshop on Sea Cucumber Fisheries: an Ecosystem Approach to Management in the Indian Ocean (SCEAM Indian Ocean), Mazizini, Zanzibar, the United Republic of Tanzania, 12-16 November 2012. FAO Fisheries and Aquaculture Report. No. 1038. Rome, p. 92.

Hoareau, T., Boissin, E., Paulay, G., Bruggeman, H., 2013. The Southwestern Indian Ocean as a potential marine evolutionary hotspot: perspectives from comparative phylogeography of reef brittle-stars. J. Biogeogr. 40, 2167-2179. http:// dx.doi.org/10.1111/jbi.12155.

Le Gallic, 2007. The use of trade measures against illicit fishing: economic and legal considerations. Ecol. Econ. 1-9, 02846.

Muthiga, N., Conand, C., 2014. Sea Cucumbers, a Poorly Understood but Important Coastal Resource: a Regional Analysis to Improve Management. WIOMSA Book Series No. 14.

Mulochau, T., Conand, C., 2008. Holothurians and other echinoderms of the Glorieuses Islands (Scattered Islands of the Indian Ocean). SPC Beche-de-Mer Inf. Bull. 28, 34-39.

Mulochau T., Conand C., Andréfouët S., Stöhr S., Boissin E., Mah C., Eleaume M. and Chabanet P. First inventory of the Echinoderms from Juan de Nova (Scattered Islands, France) in the Mozambique Channel, South Western Indian Ocean. Western Indian Ocean Journal of Marine Science (in revision)

Obura, D., 2012. The diversity and biogeography of the western Indian Ocean reefbuilding corals. PLoS One 7 (9), e45013.

O'Hara, T.D., Hugall, A.F., Thuy, B., Moussalli, A., 2014. Phylogenomic resolution of the class Ophiuroidea unlocks a global microfossil record. Curr. Biol. 24, $1874-1879$.

O'Loughlin, M., Mackenzie, M., 2013. Asterinid seastars from the Mozambique Channel (Echinodermata: Asteroidea: Asterinidae). Zootaxa 3613 (2), 176-180.
Osterblom, H., 2014. Catching up on Fisheries Crime. Conservation Biology. http:// dx.doi.org/10.1111/cobi.12229.

Pouget, M., 2005. Abundance and distribution of holothurians on the fringing reef flats of Grande Terre, Mayotte, Indian Ocean. SPC Beche-de-mer Inf. Bull. 21, $22-26$.

Poupin, J., 2015. Crustacea of Juan de Nova Island (Decapoda, Stomatopoda) compared with nearby Islands in the Mozambique Channel. Acta Oecologica. http://dx.doi.org/10.1016/j.actao.2015.04.001 (in this issue).

Purcell, S.W., Mercier, A., Conand, C., Hamel, J.-F., Toral-Ganda, V., Lovatelli, A., Uthicke, S., 2013. Sea cucumber fisheries: global analysis of stocks, management measures and drivers of overfishing. Fish Fish. 14 (1), 34-59.

Quod, J.P., Barrère, A., Chabanet, P., Durville, P., Nicet, J.B., Garnier, R., 2007. La situation des récifs coralliens des îles Eparses françaises de l'océan indien. Rev. d'Ecol. (Terre Vie) 62, 3-16.

Rowe, F.W.E., Richmond, M., 2011. Phylum echinodermata. Echinoderms. In: Richmond, M.D. (Ed.), A Field Guide of the Seashores of Eastern Africa and the Western Indian Ocean Islands. Sida/Wiomsa, p. 464.

Samyn, Y., Tallon, 2005. Zoogeography of the shallow-water holothuroids of the western Indian Ocean. J. Biogeogr. 32, 1523-1538.

Samyn, Y., VandenSpiegel, D., Massin, C., 2006. Taxonomie des holothuries des Comores, vol. 1. AbcTaxa, p. 130 i-iii.

Stöhr, S., Conand, C., Boissin, E., 2008. Brittle stars (Echinodermata: Ophiuroidea) from La Réunion and the systematic position of Ophiocanops Koehler, 1922. Zool. J. Linn. Soc. 153, 545-560.

TAAF, 2014. Opération de lutte contre la pêche illégale aux îles Eparses. http://www. taaf.fr/Operation-de-lutte-contre-la-peche-illegale-aux-iles-Eparses-669.

FAO Fisheries Technical Paper. No. 516. Rome, FAO. In: Toral-Granda, V., Lovatelli, A. Vasconcellos, M. (Eds.), 2008. Sea Cucumbers. A Global Review on Fishery and Trade, p. 319.

UICN, "Palme IFRECOR 4ème édition : les lauréats 2014-Communiqué de presse," Documentation Ifrecor, consulté le 10 décembre 2014, http://ifrecor-doc.fr/ items/show/1554.

Vergonzannes, G., 1977. Etude sur les Mollusques et les Echinodermes récifaux des Iles Glorieuses (nord-ouest de Madagascar). Bionomie et évaluations quantitatives. Thèse d'Océanographie. Université de Bretagne occidentale, France, Brest. 